\title{
New evidence of Neoarchean crustal growth in southern São Francisco Craton: the Carmópolis de Minas Layered Suite, Minas Gerais, Brazil
}

\author{
Novas evidências de crescimento crustal neoarqueano no Cráton \\ São Francisco meridional: a Suite Acamadada Carmópolis de Minas, \\ Minas Gerais, Brasil
}

\section{Luís Emanoel Alexandre Goulart ${ }^{1 *}$, Mauricio Antonio Carneiro², Issamu Endo ${ }^{3}$, Marcos Tadeu de Freitas Suita ${ }^{3}$}

\begin{abstract}
The Carmópolis de Minas Layered Suite is situated in the Campo Belo Metamorphic Complex domain, Minas Gerais, SE Brazil, which, together with other metamorphic complexes in the surroundings of the Quadrilátero Ferrifero, composes the Archean sialic crust of the southern part of the Sáo Francisco Craton. This suite encompasses a remaining segment of a magmatic arc, which is deformed and metamorphosed to upper amphibolite-granulite facies. It shows layered and massive strata, constituted by rock types with lithogeochemical signature equivalent to low- $\mathrm{K}_{2} \mathrm{O}$ tholeiitic series. Both tholeiitic and calc-alkaline magmatism phases were identified. Amphibolite and metarhyolite samples were used for zircon $\mathrm{U}-\mathrm{Pb}$ dating using MC-LA-ICP-MS. The amphibolite zircons yielded ${ }^{232} \mathrm{Th} / 238 \mathrm{U}$ ratios $\approx 0.17-0.83$ and a Concordia age of $2,752 \pm$ $18 \mathrm{Ma}$. This interval yields an approximation to minimum age of the calc-alkaline phase. The metarhyolite zircons yielded ${ }^{232} \mathrm{Th} /{ }^{238} \mathrm{U}$ ratios $\approx 0.25-0.66$ and ages of $2,713 \pm 9.9$ and $2,710 \pm 31 \mathrm{Ma}$. This variation was interpreted as the minimum age interval of the calc-alkaline phase. One of the metarhyolite samples yielded two inherited zircon populations. These populations were dated at 3,374 \pm 30 and 2,859 $\pm 23 \mathrm{Ma}$, suggesting the contribution of older crusts in the genesis of the suite. The results showed that the genesis of this suite represents an episode of juvenile arc crust formation during the Rio das Velhas Tectonotermal Event (2,780 Ma). This syn- to late-orogenic episode involved arc development, tholeiitic to calc-alkaline magmatism, metamorphism, and crustal recycling.
\end{abstract}

KEYWORDS: magmatic arc; U-Pb geochronology; calc-alkaline; tholeiitic; Archean.
RESUMO: A Suite Acamadada Carmópolis de Minas está situada no dominio do Complexo Metamórfico Campo Belo, Minas Gerais, SE-Brasil, que, junto a outros complexos metamórficos nos arredores do Quadrilátero Ferrifero, compóem a crosta siálica arqueana da parte meridional do Craton São Francisco. Essa suite compreende um segmento remanescente de arco magmático, deformado e metamorfisado em fácies anfibolito-superior a granulito. Exibe estratos acamadados e maciços, constituidos por litotipos com assinatura litogeoquímica equivalente a uma série tholeiitica de baixo- $\mathrm{K}_{2} \mathrm{O}$. Uma fase de magmatismo tholeiitico e outra de magmatismo cálcio-alcalino foram identificadas. Uma amostra de anfibolito e duas de metarriolito foram utilizadas para datação U-Pb em zircóes usando MC-LA-ICP-MS. O anfibolito apresentou zircóes com razóes ${ }^{232} \mathrm{Th}^{238} \mathrm{U} \approx 0,17-0,83$ e idade concórdia de $2.752 \pm 18 \mathrm{Ma}$. Esse resultado foi interpretado como idade minima da fase tholeiitica. As amostras de metarriolito apresentaram zircōes com razóes ${ }^{232} \mathrm{Th}{ }^{238} U \approx$ $0,25-0,66$ e foram datadas em $2.713 \pm 9,9$ e $2.710 \pm 31$ Ma. Esse intervalo fornece uma aproximação para a idade minima da fase cálcio-alcalina. Uma das amostras de metarriolito apresentou duas populaçôes de zircôes herdados. Essas populaçóes foram datadas em $3.374 \pm 30$ e 2.859 $\pm 23 \mathrm{Ma}$, sugerindo a contribuição de crostas mais antigas na gênese da suite. Os resultados demonstram que a gênese dessa suite representa um episódio de formaçáo de crosta juvenil durante o Evento Tectonotermal Rio das Velhas $(2.780 \mathrm{Ma})$. Esse episódio sin a tardi-orogênico envolveu desenvolvimento de arco, magmatismo tholeiítico a cálcio-alcalino, metamorfismo e reciclagem crustal.

PALAVRAS-CHAVE: arco magmático; geocronologia U-Pb; cálcio-alcalino; tholeititico; Arqueano.

\footnotetext{
1Post-graduation Program in Crustal Evolution and Natural Resources, Geology Department at Mining School of Universidade Federal de Ouro Preto - UFOP, Ouro Preto (MG), Brazil. E-mail: goulart.luisemanoel@gmail.com

${ }^{2}$ Centro Federal de Educação Tecnológica de Minas Gerais, Unidade de Ensino Descentralizada de Araxá, Araxá (MG), Brazil. E-mail: mauricio_araxa@hotmail.com ${ }^{3}$ Geology Department at Mining School of, Universidade Federal de Ouro Preto - UFOP, Ouro Preto (MG), Brazil. E-mails: issamu.endo@gmail.com; suita@degeo.ufop.br *Corresponding author

Manuscrito ID 29929. Submetido em: 25/02/2013. Recebido em: 29/08/2013.
} 


\section{INTRODUCTION}

The Archean tectonic evolution of the southern portion of the São Francisco Craton (SFC) was marked by episodes of formation, thickening, and consumption of crust, as proposed by Carneiro (1992), Machado \& Carneiro (1992), Machado et al. (1992, 1996), Noce et al. (1998), Silva et al. (2000), Teixeira (1985), and Teixeira et al. (2000), among others. Among this collection of papers, those of Teixeira et al. $(1996,1998)$ stand out, because they point to a polyphase history with three periods of intense tectono-magmatic activity between the Paleo- and Neoarchean Eras. According to these authors, the first period incorporates ages older than $\approx 3.1-2.9 \mathrm{Ga}$ and contributes to the set of oldest $\mathrm{U}-\mathrm{Pb}$ ages of the South American Platform. The ages in this range represent a fruitful period of crustal formation and thickening (e.g. Teixeira et al. 1996, 1998, Carneiro et al. 1998; Hartmann et al. 2006). U-Pb ages with this order of magnitude were obtained in zircons from the gneisses of Campo Belo Metamorphic Complex (CBMC; Teixeira et al. 1998), the Belo Horizonte Metamorphic Complex (CMBH; Teixeira et al. 1996), the mafic-ultramafic volcanic sequence of the Piumhi greenstone belt (Machado \& Schrank 1989), and the metasedimentary rocks of the Rio das Velhas Supergroup (SGRV; Machado et al. 1996; Noce et al. 2005; Hartmann et al. 2006). This period is also recorded in Sm-Nd TDM model ages, and $\mathrm{Pb} / \mathrm{Pb}$ and $\mathrm{Rb}-\mathrm{Sr}$ isochron ages (Carneiro 1992; Machado \& Carneiro 1992; Machado et al. 1992; Teixeira et al. 1996, 1998), obtained in the metamorphic complexes that surround the Quadrilátero Ferrífero mining district. The second event occured between $\approx 2.9-2.8 \mathrm{Ga}$. Several studies in zircons from the migmatites neossome of the CBMC (Teixeira et al. 1998) and BHMC (Noce 1995; Noce et al. 1998) record an episode of highgrade metamorphism and migmatization between 2860 and $2839 \mathrm{Ma}$. In addition, processes of oceanic crust formation during this period are suggested by $\mathrm{Sm}-\mathrm{Nd}$ isochron age of $2863 \pm 65 \mathrm{Ma}$, obtained in komatiitic rocks from the Morro do Ferro greenstone belt (Pimentel \& Ferreira Filho 2002). There is no mention in the literature of records on the 2860 and $2839 \mathrm{Ma}$ event in the Bonfim Metamorphic Complex. This fact indicates that the tectonic evolution of this unit was distinct from the other metamorphic complexes in this region. However, the $\mathrm{CMB}$ records evidence of an event of magmatism and crustal reworking between $\approx 2780$ and $2700 \mathrm{Ma}$ (e.g. Carneiro 1992; Machado \& Carneiro 1992). This event was defined by Carneiro (1992) as the Rio das Velhas Tectono-thermal Event (RVTE) and comprises the third period of tectonic activity described by Teixeira et al. (1996, 1998), also referred to as Rio das Velhas Orogeny. RVTE involved reworking of older TTG gneisses during the evolution of a continental margin, generating metamorphism (Carneiro 1992) and producing andesitic to calc-alkaline magmatism (Carneiro 1992; Machado et al. 1992, 1996; Noce et al. 2005). The apex of this event was marked by a collisional stage between 2752 and $2700 \mathrm{Ma}$ (e.g. Carneiro 1992; Noce et al. 1998), which included the Nova Lima Group sedimentation (Hartmann et al. 2006), and, at the final stages of stabilization of the orogen, an extensional event, responsible for the emplacement of mafic-ultramafic bodies in the crust (Pinese 1997; Carneiro et al. 2004) and a syn- to late-orogenic granitogenesis (Carneiro 1992; Noce 1995; Teixeira et al. 1996; Romano 1989).

Recent work by Romano et al. (2013) and Lana et al. (2013), corroborating the previous papers, proposed three main tectono-magmatic events of TTG crust formation. The authors named these events as Santa Bárbara (3220 $3200 \mathrm{Ma}$ ), Rio das Velhas I (RV I; 2930 - $2900 \mathrm{Ma}$ ), and Rio das Velhas II (RV II; 2800 - 2770 Ma). After the RV II Event, the coalescence of the crustal segments that currently represent the metamorphic complexes in the vicinity of the Quadrilátero Ferrífero was recorded, where an extensive 2760 2700 Ma potassic magmatic event took place, marking the Archean cratonic core stabilization (e.g. Lana et al. 2013).

The isotopic records of these events are also identified at the Campo Belo Metamorphic Complex domain. The current tectonic models (e.g. Teixeira et al. 1998; Carneiro et al. 1998; Campos \& Carneiro 2008) indicate that the crustal segment represented by CMCB collided with the N/NE sialic blocks, over the probable Neoarchean continental margin, corresponding to SW limit of the Quadrilátero Ferrífero mining district (Carneiro 1992; Machado \& Carneiro 1992; Campos \& Carneiro 2008). In contrast, either there is no information about the style of margin in the block opposite $(\mathrm{CMCB})$ or available information is more generalist, addressing only the collisional orogen as a whole.

In this sense, within the Campo Belo Metamorphic Complex and close to the inferred limit with the Bonfim Metamorphic Complex crops out the Carmópolis de Minas Layered Suite (CMLS - e.g. Goulart \& Carneiro 2013). Previous work by Carneiro et al. (2007) originally correlated the CMLS rocks with the Neoarchean Ribeirão dos Motas Layered Sequence (RMLS), which crops out at the SW studied area. This unit was interpreted by Carvalho Júnior (2001) as a stratiform layered intrusion, correlated to the mafic-ultramafic volcanic rocks of the Rio das Velhas Supergroup. Whole-rock Sm-Nd isotope constraints (Carneiro et al. 1997, 2004) yielded an isochron age of $c a$. 2.79 Ga for the Ribeirão dos Motas Layered Sequence, supporting this interpretation.

Nevertheless, later works (e.g. Goulart \& Carneiro 2013; in press) observed evidence of a tardy calc-alkaline magmatic phase in the Carmópolis de Minas Layered Suite, not observed 
in the Ribeirão dos Motas Layered Suite. These evidences consist of the emplacement of intermediate to acidic rocks, posterior to the tholeiitic magmatic phase. Given the new geological constraints, Goulart et al. (2013, unpublished) and Goulart \& Carneiro (2013, in press) characterized the SACM as Neoarchean juvenile magmatic arc-related suite, correlated to the late RV II. The present work shows the preliminary results of U-Pb (LA-ICP-MS) geochronological dating in zircons from rocks of the Carmópolis de Minas Layered Suite, which discusses: 1) ages of the phases of tholeiitic and calc-alkaline magmatism; and 2) possible implications of this unit in the crustal evolution of the Southern São Francisco Craton.

\section{LOCATION AND GEOLOGIC CONTEXT OF CARMÓPOLIS DE MINAS LAYERED SUITE}

Carmópolis de Minas Layered Suite comprises a crustal segment of the Campo Belo Metamorphic Complex, located southwest of the Quadrilátero Ferrifero $(\mathrm{QF})$, in the Carmópolis de Minas municipality (State of Minas Gerais, Figs. 1 and 2). This suite is positioned in a sinformal structure approximately $30 \mathrm{~km}$ long (Carmópolis de Minas Synclinal - Fig. 2). To the north, the structure axis trends NE-SW and inflects NW-SE to the south.

Contacts between the Carmópolis de Minas Layered Suite and the CBMC TTG gneisses are inferred. Along the unit, granitoids and three mafic dyke systems (two NW-SE and one NE-SW direction), designated as Lençóis I / II and Timboré (e.g. Carneiro et al. 2007) suites, intrude into this stratigraphic sequence. Remnants of detrital and chemical sedimentary units crop out subordinately and in small volume. These rocks consist of metachert, gondite, magnetitite layers, and quartzite, which occasionally occur interspersed with amphibolite lenses.

The suite is composed of layered and massive, plutonic or sub-volcanic, mafic-ultramafic to felsic lithotypes, metamorphosed at amphibolite to granulite facies conditions (Figs. 3A to C). The typical outcrops of the CMLS show NE-SW-vertical to sub-vertical layering. In the syncline closing, the magmatic layering shows expressive deformation, exhibiting well-defined NE-SW-oriented M-fold axes (Fig. 3B). Geochemical and isotopic constraints (Goulart et al. 2013, unpublished; Goulart \& Carneiro 2013, in press) indicate that low $\mathrm{Mg}$ number $(\mathrm{Mg} \#<57.87$, except metaultramafic cumulates), low $\mathrm{K}_{2} \mathrm{O}$ contents $(0.1-1.45$ wt.\%), and positive to slightly negative $\varepsilon \mathrm{Nd}(\mathrm{t})$ values $(+13.14$ to -0.25 ) are ubiquitous features of these rocks. According to the cited authors, the predominant low $\mathrm{Mg \#}$ values in association with vestiges of metasedimentary rocks indicate that the SACM protolith may have been derived from more evolved magmas, which in turn were fractionated from primary magmas, to then be housed at shallower depths in the crust. The low- $\mathrm{K}_{2} \mathrm{O}$ rocks, as opposed to high- $\mathrm{K}_{2} \mathrm{O}$ and TTG suites currently known in the sialic substrate of Southern CSF (e. g. Alkmin \& Noce 2006; Campos \& Carneiro 2008; Romano et al. 2013, Lana et al. 2013), indicate the SACM to be an Archean metamorphic equivalent of modern arc-related tholeiitic suites of the boninite-basalt-andesite-rhyolite type, suggesting that their protoliths were originated in a juvenile oceanic arc setting (see Gill 1981; Leat et al. 2003 Tamura et al. 2009).

The composition of the lithological assemblage is in agreement with the expected average proportions between tholeiitic and calc-alkaline rocks from juvenile magmatic arc-related suites (e.g. Gill 1981). Tholeiitic rocks are volumetrically predominant and represent several metamorphic lithotypes as arc-related amphibolite-metaultramafic cumulates and metamorphosed arc-related basic to intermediate rocks.

The metamafites correspond to several varieties of amphibolite and leucoamphibolite. Garnet-amphibolite was described and occurs in small amounts. These rocks are composed of plagioclase, hornblende, pyroxene, Fe-Ti-oxides, garnet, and quartz. Metasomatized rocks contain actinolite, Na-plagioclase, biotite, epidote, scapolite, quartz, and carbonate. The meta-metaultramafic rocks are orthopyroxenite, hornblendite, plagioclase-metapiroxenite, meta-olivine-websterite, and meta-harzburgite. Garnet-bearing amphibolite and garnet-bearing websterite have been described, but they occur in small amounts. The lithotypes are composed of orthopyroxene, clinopyroxene, hornblende, olivine, garnet, spinel, Fe-Ti-oxides, and sulfides. The secondary paragenesis is formed by serpentine, talc, tremolite/Mg-hornblende, and chlorite in smaller quantities. Metadunite and metalherzolite are unusual and present original mineralogy intensely replaced by secondary paragenesis. These rocks keep relict primary textures such as euhedral twinned clinopyroxene crystals showing rim recrystallization (mantled texture), euhedral tabular plagioclase crystals with recrystallized cores (ghost crystals), and several relict cumulatic textures constituted by plagioclase, clinopyroxene, orthopyroxene, and olivine in lesser importance. The calc-alkaline rocks are less abundant and consist of metamorphosed rhyodacitic/rhyolitic rocks. These lithotypes occur as felsic injections, parallel to sub-parallel to the metaultramafic-amphibolitic bedding. Granitoids crop out in some portions of the unit, but the relationship of these with the CMLS is not known. These rocks are formed by Na-plagioclase, K-feldspar, and quartz. Mafic minerals are biotite, pyroxene, and/or hornblende and $\mathrm{Fe}$-Ti-oxides but occur in small amounts. 


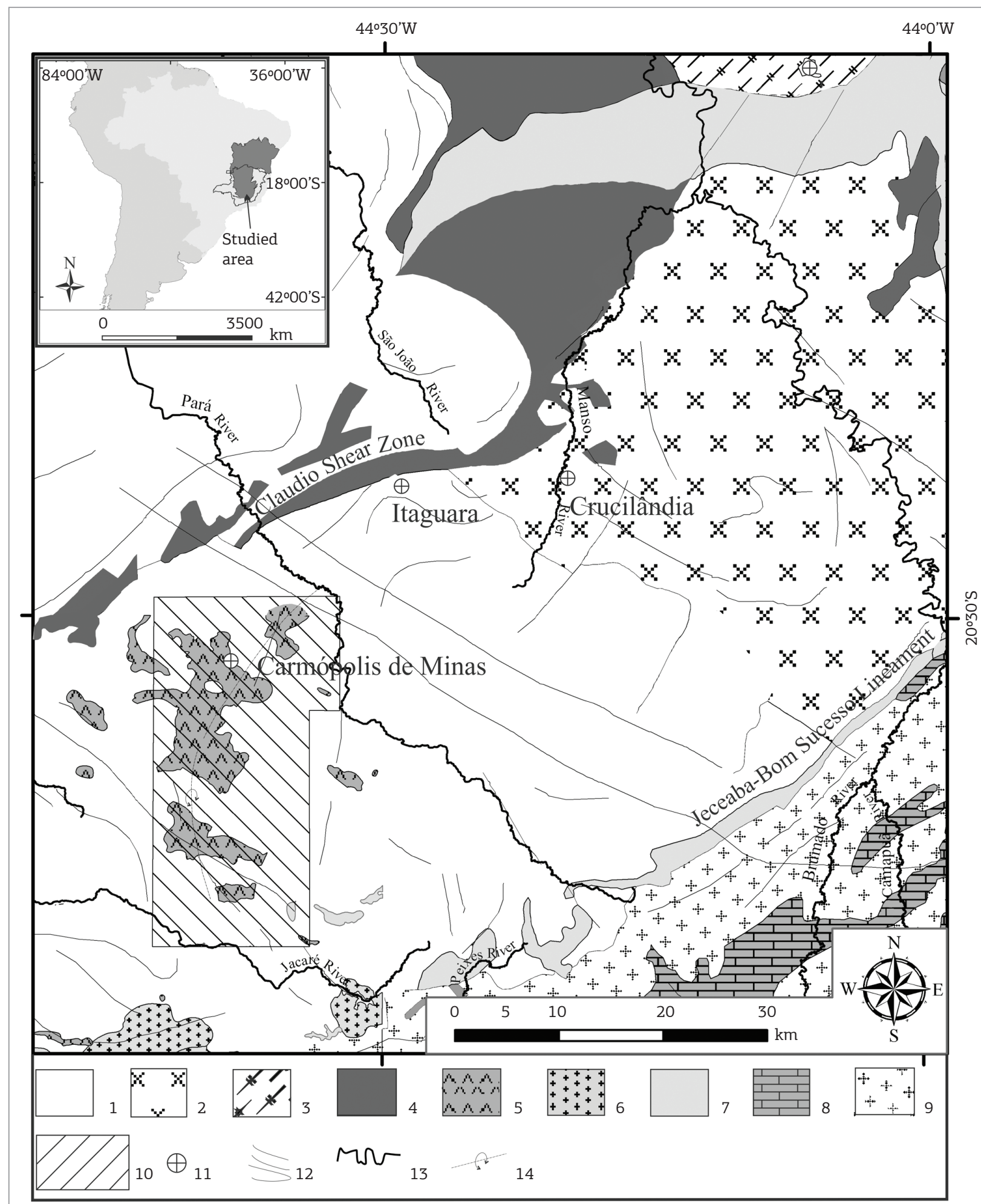

1: Campo Belo Metamorphic Complex; 2: Bonfim Complex; 3: Belo Horizonte Complex; 4: Rio das Velhas Supergroup (Archean greenstone sequence); 5: Carmópolis de Minas Layered Suite; 6: Archean granitoids; 7: Minas Supergroup (Paleoproterozoic supracrustal sequences); 8: (undifferentiated Paleoproterozoic greenstone sequences); 9: Paleoproterozoic Granitoids; 10: studied area; 11: towns; 12: undifferentiated lineaments; 13: drainage; 14: inferred syncline.

Figure 1. Simplified geologic map of southern São Francisco Craton showing the location of the study area and part of the SW limit of the Quadrilátero Ferrífero. The Carmópolis de Minas Layered Suite boundaries are still represented as in Carneiro et al. (2007). In the upper left corner the location of the study area is shown in relation to the Southern São Francisco Craton (dark gray area). Sources: Leite et al. (2004), Carneiro et al. (2007). 


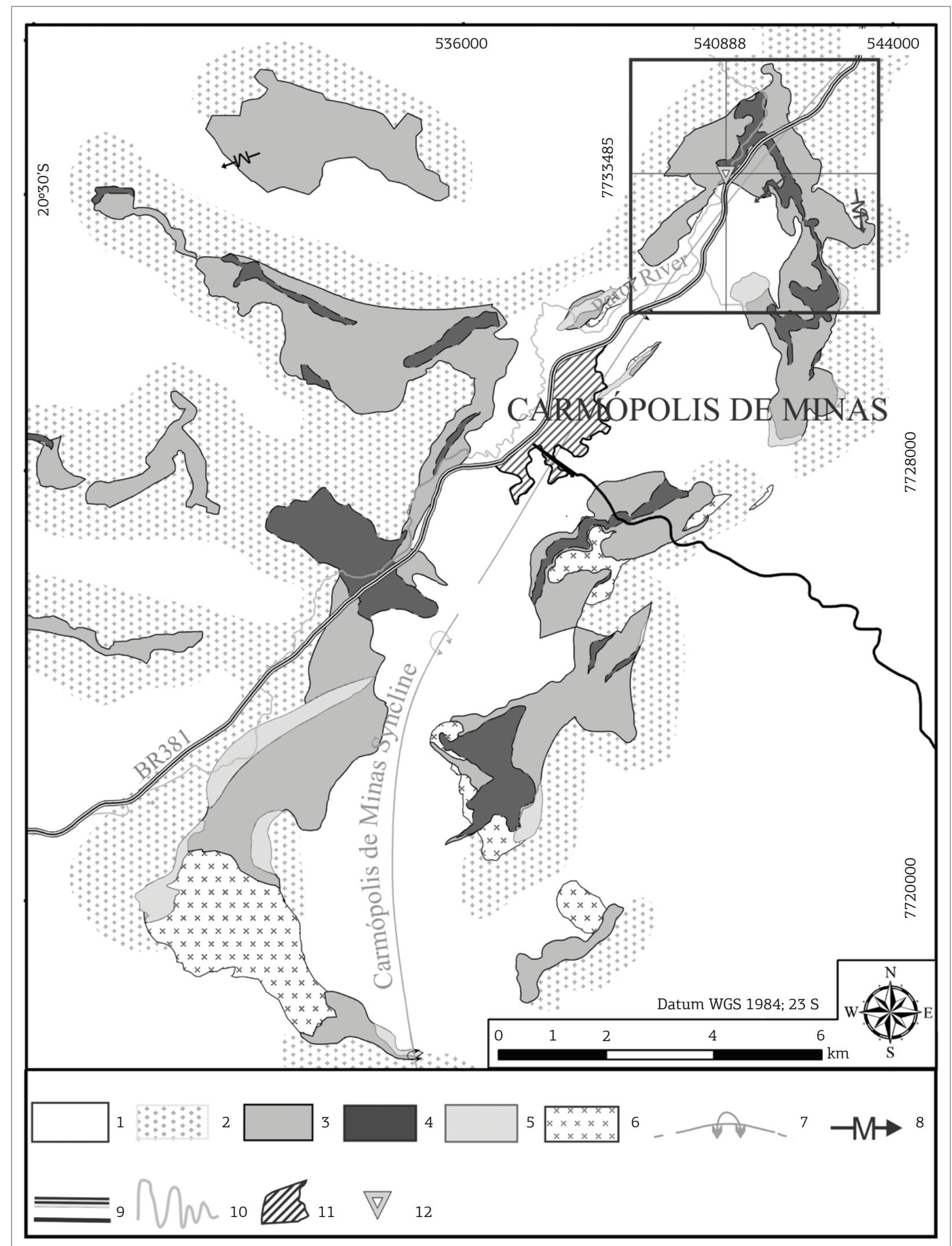

1 and 2: undifferentiated gneisses of the CBMC; 3: metamafic rocks of the CMLS; 4: metaultramafic rocks of the CMLS; 5: Chemical metasedimentary rocks; 6: Metagranitoid; 7: regional-scale fold axis (inverted syncline); 8: second-order fold axis; 9: roads and highways; 10: rivers; 11: town; 12: sampling site.

Figure 2. Geologic map of Carmópolis de Minas Layered Suite. 

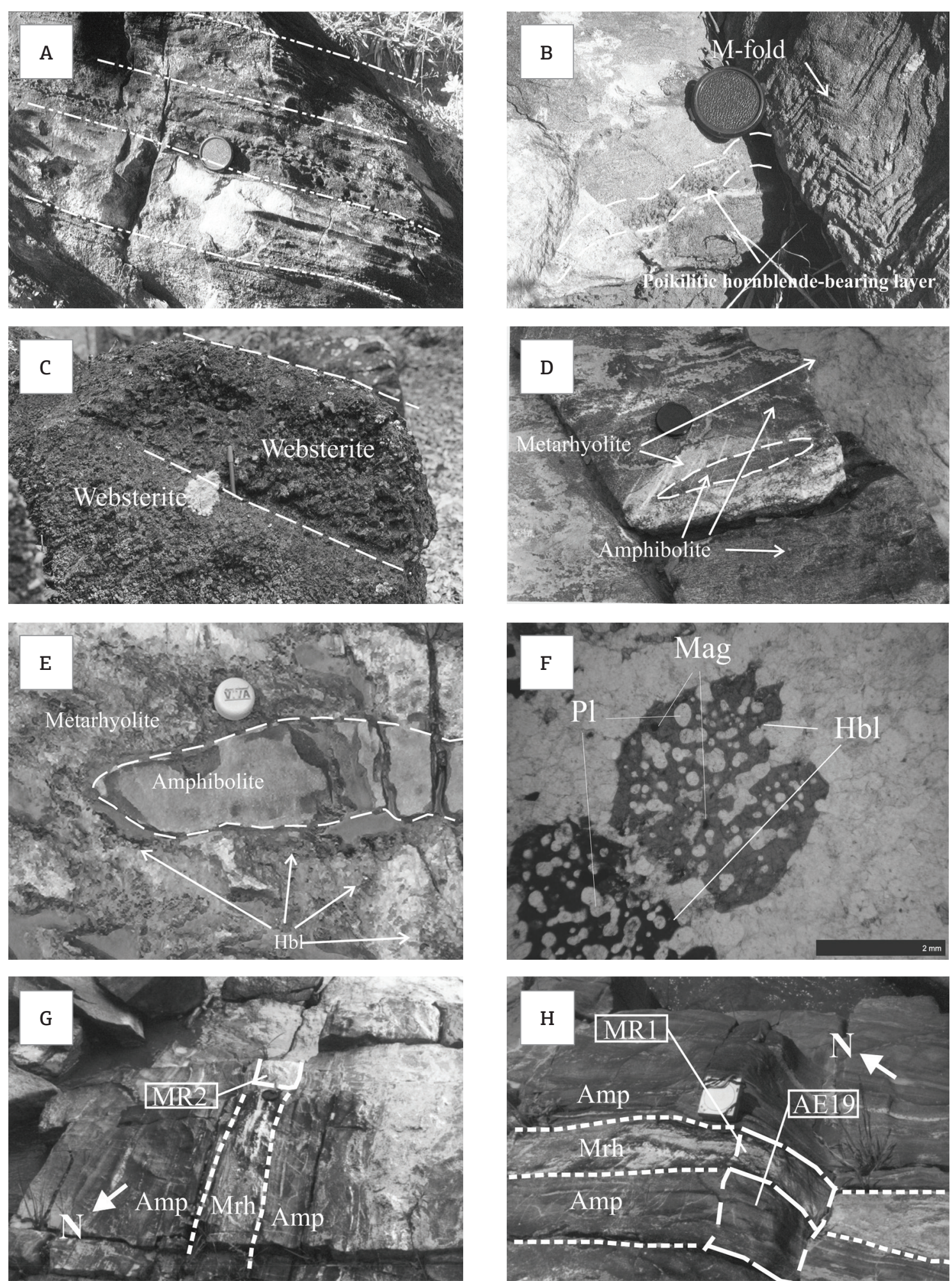

Figure 3. Carmópolis de Minas Layered Suite typical structures. (A) Magmatic layering constituted by leucoamphibolite and amphibolite. (B) "M"-folded magmatic layering constituted by leucoamphibolite and amphibolite, with stratification formed by the accumulation of poikilitic hornblende crystals. (C) Magmatic layering in meta-websterite. (D) and (E) Amphibolite enclave in metarhyolite. These structures are associated with the presence of poikilitic hornblende ( $\mathrm{Hbl})$. (F) Thin section showing poikilitic hornblende crystals (Hbl) hosting plagioclase (Pl) and magnetite (Mag). Observe the euhedral to subhedral habit of the crystals (PPL, enlargement $5 \mathrm{X})$. (G) and (H) Outcrop showing the sampled metarhyolite and amphibolite. The acidic injections are parallel to sub-parallel to the amphibolite strata. 
The Nd-Sr isotope data that Goulart \& Carneiro (2013, in press) obtained point to two magmatic sources for the SACM rocks. Positive $\varepsilon_{\mathrm{Nd}(\mathrm{t})}$ values $(>+0.41)$ point out that the tholeiitic rocks are mantle-derived, whereas the calc-alkaline rocks, presenting slightly negative $\varepsilon_{\mathrm{Nd}(\mathrm{t})}$ values (-0.25), show that they may have been generated in a sin- to late-orogenic phase by sub-arc crust anatexis.

Several field evidences confirm the two magmatic phases during SACM formation:

- Mafic enclaves, microgranular and/or orbicular aggregates, and poikilitic euhedral crystals of hornblende, ortho- and clinopyroxene (Figs. 3D to F), hosting countless Fe-Ti-oxides and phenocrystal of plagioclase, are observed in the contact between amphibolite layering and felsic injections. These structures suggest assimilation of sub-arc mafic crust by felsic magmas.

Amphibolite enclaves and lenses showing low-grade metamorphic paragenesis with Na-plagioclase, epidote, actinolite, quartz, and minor biotite also occur at the felsic injections contact. According to Morgan \& London (1987), the contact between acidic melts and mafic rocks may cause metasomatism and low-grade paragenesis formation. This point of view implies that the tholeiitic and calc-alkaline magmatic phase cannot be contemporaneous, but suggests that the calc-alkaline magmatism may have involved several pulses, where not all have yet been identified.

- In the stratified domains, poikilitic crystals of pyroxene and hornblende were also observed. According to several authors (e.g. Storey et al. 1989; Seaman et al. 1995; Lindberg \& Eklund 1988), similar textures can be generated by the contact reaction of melts with distinct rheological characteristics. Regarding CMLS, these textures suggest that tholeiitic and calc-alkaline magmatic phases could have coexisted, interacted, and generated hybrid magmas.

\section{MATERIALS AND METHODS}

Sample preparation (crushing, comminution, concentration, and separation of magnetic minerals) was performed in LOPAG - Laboratory for Sample Preparation for Geochemistry and Geochronology, Geology Department of the Ouro Preto Federal University. The non-magnetic fractions were analyzed by LA-MC-ICP-MS (Laser Ablation) at the Geochronology Laboratory of the Geosciences Institute of Brasília University. Zircon crystals were separated by means of methyl iodide and selected manually by means of a stereoscope. The selected crystals were mounted in an araldite circular section $2.5 \mathrm{~cm}$ in diameter and then polished. The BSE (backscattering electron probe) images of zircon grains were obtained using a Leica MZ 125 optical microscope and a Jeol JSM 5800 scanning electron microscope (Fig. 4). The isotopic ratios were obtained from the MC-ICP-MS (Neptune) equipment coupled to a microprobe (New Wave UP 213). Specific data on the configuration of the Faraday collectors, correction of mass bias, standards, external correction and of laser conditions, corrections of common $\mathrm{Pb}$, calculation of ratios, and error estimation are detailed in Stacey \& Kramers (1975), Jackson et al. (2004), Kawashita \& Chemale Jr. (2006), and Chemale et al. (2008, 2009). The ages were calculated using the Isoplot 3.0 program (Ludwig 2000). The analysis results are provided in Tab. 1.

\section{RESULTS}

Two metarhyolite samples (MR1 and MR2) and one amphibolite sample (AE19) were analyzed. These samples were obtained from the same outcrop, located in the northernmost part of CMLS, at the left bank of the Paiol River, which corresponds to the closing of the Carmópolis de Minas Synclinal (UTM 540888/7733485; Figs. 2, 3G, and 3H). This place was chosen for the large lithotype diversity, with peculiar structures, such as abundant poikilitic hornblende crystals and mafic enclaves observed in metarhyolite. The selected grains showing low metamictization degree and sizes compatible with the laser spot diameter were analyzed. Despite the fact that the zircons had shown low contrast in the BSE imaging, the analyses were directed preferentially to the crystal cores, because the sizes of these domains are more compatible with the laser spot. Morphology and isotopic characteristics of zircon grains are presented in Figs. 4 and 5. Geochronological results are presented in Tab. 1 and Fig. 5.

\section{Sample AE19}

This sample is fine to medium grained and composed of hornblende, plagioclase, and quartz. Accessory minerals are titanite, zircon, apatite, and Ti-magnetite. This sample constitutes zircons D1, D2, D3, D11, D13, and D16. The grains present short and elongated prismatic shapes, occasionally with sub-rounded rims, as a function of metamorphic overgrowth. Internal domains are homogeneous with some fracturing.

Samples and standards were corrected after $\mathrm{Pb}$ and $\mathrm{Hg}$ blanks; ${ }^{207} \mathrm{~Pb} /{ }^{206} \mathrm{~Pb}$ and ${ }^{206} \mathrm{~Pb} /{ }^{238} \mathrm{U}$ ratios were corrected after common $\mathrm{Pb}$; common $\mathrm{Pb}$ assuming as concordant age ${ }^{206} \mathrm{~Pb} /{ }^{238} \mathrm{U} *{ }^{207} \mathrm{~Pb} /{ }^{235} \mathrm{U} ;{ }^{235} \mathrm{U}=1 / 137.88{ }^{*} \mathrm{U}_{\text {total }}$; Standard: GJ-1 (Jackson et al. 2004); ${ }^{232} \mathrm{Th} /{ }^{238} \mathrm{U}={ }^{232} \mathrm{Th} / 238 \mathrm{U}$ * 0.992743. Errors were calculated with 1 sigma (\% for isotopic ratios, absolute ages). 7. Discordance $\%=100 *$ $\left(1-{ }^{206} \mathrm{~Pb} /{ }^{238} \mathrm{Ut} /{ }^{207} \mathrm{~Pb} /{ }^{206} \mathrm{~Pb}\right)$. 
Despite the weak contrast of the images, it was possible to distinguish a blurred, oscillatory fine zoning in some crystals. Some zircons present metamorphic overgrowth separated from the internal domains by fractures with dissolution-resorption structures and inclusions of silicate or phosphate crystals. Some grains exhibit peripheral domains more enriched in inclusions. The analyses revealed moderate to high ${ }^{232} \mathrm{Th} /{ }^{238} \mathrm{U}$ ratios $(0.17-0.83$; Tab. 1$)$. The obtained results are concordant to strongly discordant $(2-65 \%$ discordance) and consist of a large interval of ${ }^{206} \mathrm{~Pb} /{ }^{207} \mathrm{~Pb}$ ages with range from $2749 \pm 22 \mathrm{Ma}$ to $2448 \pm 22$. The analytical points defined a Pb-loss line that intercepts the Concordia in the upper part of the diagram at $2744 \pm 11 \mathrm{Ma}$ and the lower part at $252 \pm 12 \mathrm{Ma}(\mathrm{MSWD}=0.38)$, the latter with no apparent geologic meaning. These discordant results are probably correlated with the presence of internal fractures in the analyzed grains. Nevertheless, the grouping of analysis defined by zircon grains D3, D11, and D16 yielded an apparent Concordia age of $2752 \pm 18 \mathrm{Ma}$ (MSWD = 1.6; Fig. 5).

\section{Sample MR1}

Sample MR1 is composed of plagioclase, K-feldspar, quartz, and subordinate biotite and orthopyroxene. Titanite and zircon are accessory minerals. The analyzed zircons were labeled with prefixes $\mathrm{H}$ and I. The grains are predominantly prismatic, short, subhedral, and/or equidimensional, occasionally sub-rounded and double-terminated. Internal domains are ample and homogeneous. Occasionally the subtle contrasts
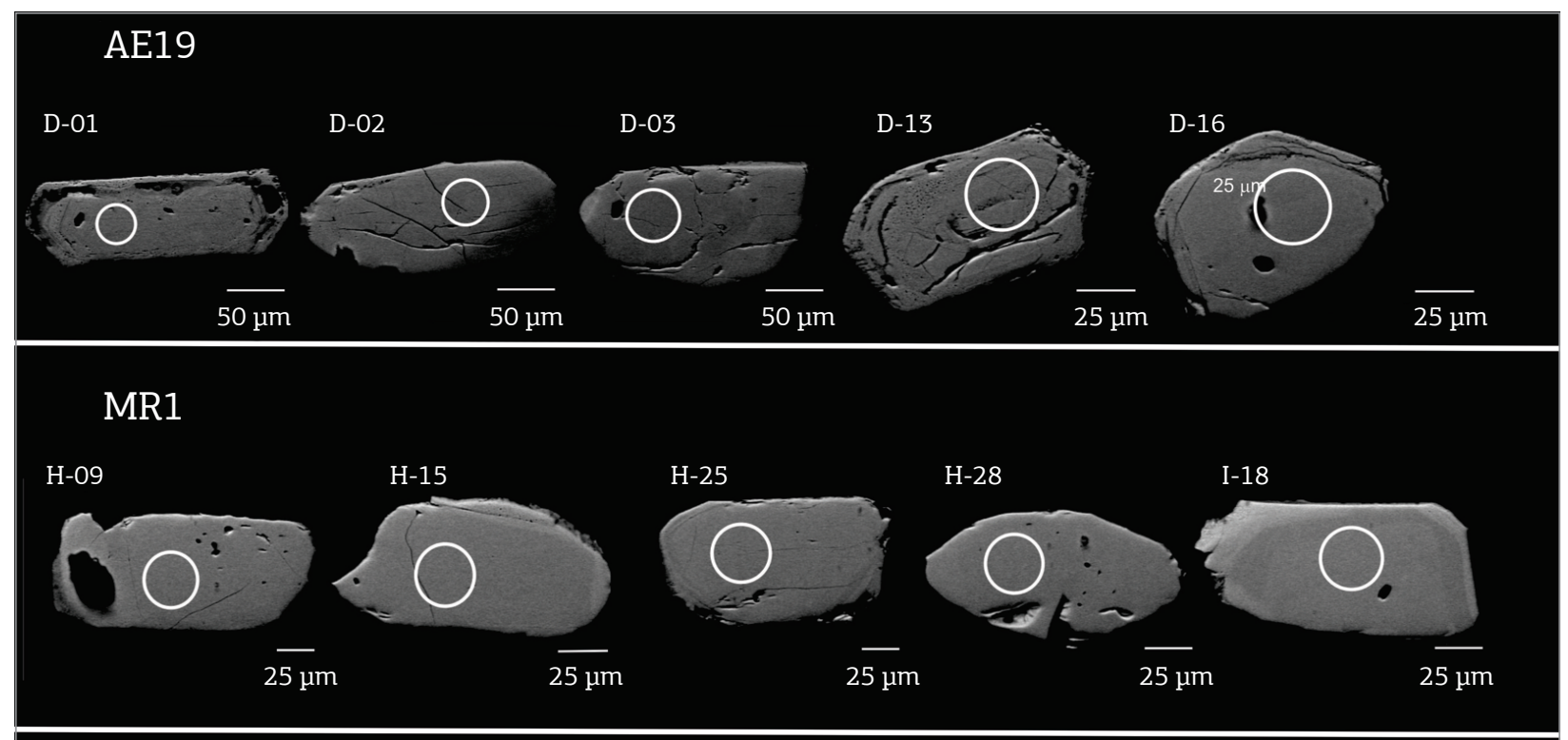

MR2

E-06

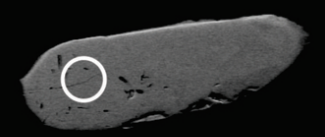

$\overline{50 \mu \mathrm{m}}$
E-08

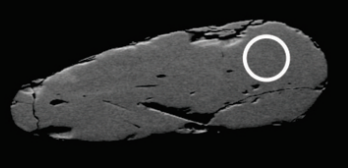

E-11

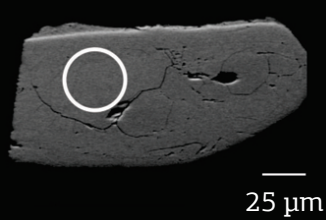

E-21

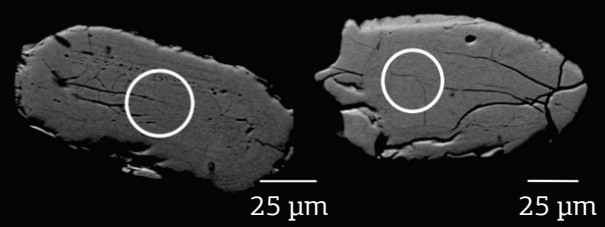

E-27

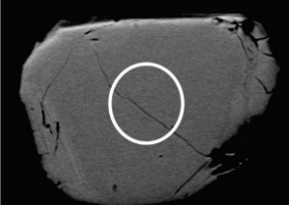

$25 \mu \mathrm{m}$
E-04

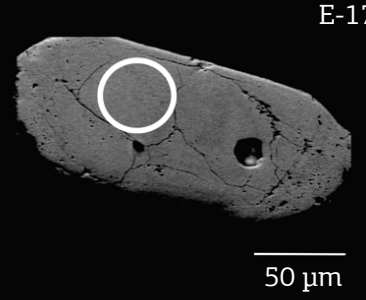

E-17

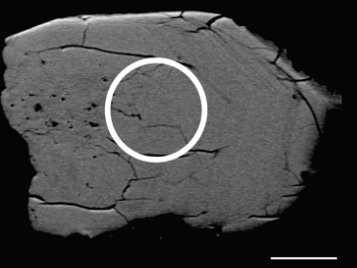

$\overline{25 \mu \mathrm{m}}$
E-24

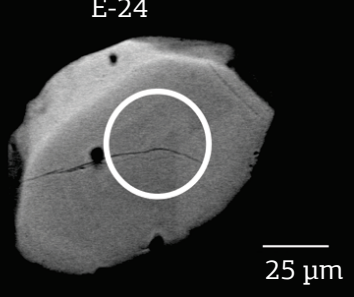

Figure 4. Backscattering electron probe images of some zircons of this study. The circles represent the position of the laser spots. 
in BSE images suggest the presence of blurred oscillatory zoning. The development of fractures is insignificant. In general, grains present peripheral domains with homogeneous texture, in some cases (zircon H25) with inexpressive concentric fractures delimiting the internal domains. Occasionally they are associated with dissolution structures, suggesting fluid percolation. Some grains present mineral inclusions. Results yielded moderate to high ${ }^{232} \mathrm{Th} /{ }^{238} \mathrm{U}$ ratios in the $0.21-0.66$ interval. Analysis from zircons H9, H15, H25, H28, and I18 presented concordant analytical points (discordance $<1 \%$ ). These results yielded a weighted mean ${ }^{206} \mathrm{~Pb} /{ }^{207} \mathrm{~Pb}$ age of 2718 $\pm 15 \mathrm{Ma}$ and an apparent Concordia age of $2713 \pm 9.9 \mathrm{Ma}$ $(\mathrm{MSWD}=1.6$; Fig. 5).

\section{Sample MR2}

The essential paragenesis of this sample is plagioclase, quartz, and K-feldspar. The mafic mineral is biotite and the accessory minerals are Ti-magnetite, titanite, apatite, and zircon.

The zircons of this sample define three populations with well-defined ${ }^{206} \mathrm{~Pb} /{ }^{207} \mathrm{~Pb}$ ages. The first population is represented by zircons E6, E8, E11, E21, and E28. The crystals are prismatic, elongated, with sub-rounded rims, and internal domains with homogeneous texture or blurred oscillatory zoning. Mineral and fluid inclusions, fracturing, and botryoidal structures are present in all grains. It is possible to distinguish with some difficulty pervasive transgressive recrystallization in weakly contrasting BSE images. These structures indicate that these zircons were partially recrystallized during medium- to high-grade metamorphism (e.g. Vavra et al. 1999; Connelly 2000; Corfu et al. 2003).

The zircon analysis yielded high ${ }^{232} \mathrm{Th} /{ }^{238} \mathrm{U}$ ratios $(\approx 0.42-0.57)$. Grains E21 and E28 showed Th and U enrichment relative to $\mathrm{Pb}$, when compared to $\mathrm{E} 6, \mathrm{E} 8$, and E11, resulting in slightly lower ${ }^{232} \mathrm{Th} /{ }^{238} \mathrm{U}$ ratios $(0.26$ and 0.32). Zircons E6, E8, E11, E21, and E28 presented concordant to discordant results $(<1-45 \%$ disc. $)$ and ${ }^{206} \mathrm{~Pb} /{ }^{207} \mathrm{~Pb}$ ages with range in ages from $\approx 2717 \pm 47$ to $2183 \pm 97 \mathrm{Ma}$. Discordant results probably reflect the presence of fractures in the zircons. Particularly, the analyses of zircons E21 and E28 resulted in apparent ${ }^{207} \mathrm{~Pb}^{206} / \mathrm{Pb}$ ages, inconsistent with the other samples of this group $(2183 \pm 97$ and $2210 \pm 31 \mathrm{Ma}$ ), but aligned with these in a radiogenic $\mathrm{Pb}$-loss line that intercepts the Concordia at $2710 \pm 31 \mathrm{Ma}$ and $773 \pm 64 \mathrm{Ma}(\mathrm{MSWD}=1.06)$. Zircons E08 and E11 (discordance $<1 \%$ ) yielded an apparent Concordia age of $2713 \pm 15 \mathrm{Ma}(\mathrm{MSWD}=0.42)$. The other zircon populations yielded well-defined ${ }^{207} \mathrm{~Pb}^{206} / \mathrm{Pb}$ ages that are distinct

Table 1. LA-MC-ICPMS analytical results

\begin{tabular}{|c|c|c|c|c|c|c|c|c|c|c|c|c|c|c|c|c|c|c|c|c|}
\hline & \multicolumn{8}{|c|}{ Isotopic ratios } & \multicolumn{8}{|c|}{ Ages (Ma) } & \multicolumn{4}{|c|}{ Geochemistry } \\
\hline & 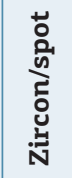 & 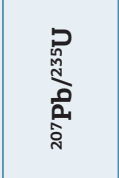 & \pm & 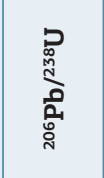 & \pm & 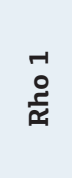 & 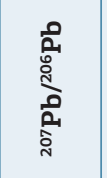 & \pm & 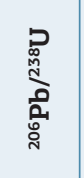 & \pm & 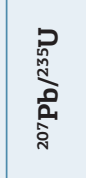 & \pm & 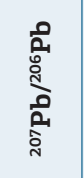 & \pm & 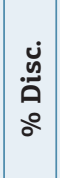 & 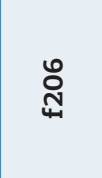 & 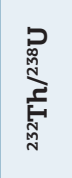 & 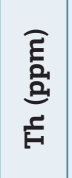 & 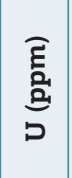 & 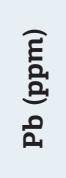 \\
\hline \multirow{6}{*}{ 岁 } & D03 & & 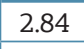 & 4 & 2.45 & 6 & 900 & 1.43 & 2777 & 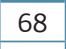 & 756 & 78 & 12 & 39 & -1 & & 53 & 14 & 7 & 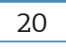 \\
\hline & D11 & 4.1099 & 1.33 & 5363 & 1.06 & 0.80 & 0.1908 & 0.81 & 2768 & 29 & 2757 & 37 & 49 & 22 & -1 & 0007 & 0.54 & 29 & 54 & 43 \\
\hline & D16 & 4.2281 & 2.23 & 0.5430 & 1.97 & 0.88 & 0.1900 & 1.05 & 2796 & 55 & 2765 & 62 & 2742 & 29 & -2 & 0008 & 0.42 & 17 & 40 & 28 \\
\hline & D01 & 5.7651 & 3.46 & 0.2453 & 0.61 & 0.18 & 0.1705 & 3.41 & 1414 & 9 & 1941 & 67 & 2562 & 87 & 45 & .0056 & 0.83 & 196 & 239 & 86 \\
\hline & D02 & 8.4533 & 1.36 & 3334 & 1.13 & 0.83 & 0.1839 & 0.76 & 1855 & 21 & 2281 & 31 & 688 & 20 & 31 & 0016 & 0.58 & 129 & 224 & 91 \\
\hline & D13 & 3.1016 & 1.18 & 0.1412 & 0.83 & 0.70 & 0.1593 & 0.84 & 852 & 7 & 1433 & 17 & 2448 & 21 & 65 & .0016 & 0.17 & 28 & 160 & 34 \\
\hline \multirow{5}{*}{ 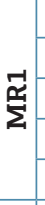 } & H09 & .453 & 2.8 & 20 & 2.4 & 0.85 & & 1.49 & 2700 & 00 & 2712 & 78 & 1 & 41 & 1 & & 0.66 & 25 & 88 & 19 \\
\hline & H15 & 13.323 & 2.08 & 0.518 & 1.36 & 0.65 & 0.187 & 1.58 & 2689 & 36 & 2703 & 56 & 2713 & 43 & 1 & 7 & 0.61 & 19 & 31 & 15 \\
\hline & H25 & 13.597 & 2.50 & 0.527 & 2.09 & 0.84 & 0.187 & 1.37 & 2730 & 57 & 2722 & 68 & 2716 & 37 & 0 & 5 & 0.55 & 39 & 71 & 35 \\
\hline & H28 & 13.416 & 1.88 & 0.522 & 1.57 & 0.84 & 0.186 & 1.03 & 2709 & 43 & 2709 & 51 & 2710 & 28 & 0 & 0.0003 & 0.53 & 45 & 85 & 38 \\
\hline & I18 & 13.687 & 2.69 & 0.526 & 2.1 & 0.80 & 0.189 & 1.63 & 2723 & 58 & 2728 & 73 & 2732 & 44 & 0 & 4 & 0.65 & 46 & 71 & 33 \\
\hline \multirow{10}{*}{$\underset{\mathfrak{\Sigma}}{\tilde{\Sigma}}$} & E01 & 2065 & 1.22 & 0.4483 & 1.02 & 0.83 & 0.2460 & 0.68 & 2387 & 24 & 2828 & 35 & 159 & 22 & 24 & 2 & 0.17 & 39 & 234 & 139 \\
\hline & E27 & 5.0331 & 2.24 & 0.6662 & 2.01 & 0.90 & 0.2834 & 0.99 & 3291 & 66 & 3348 & 75 & 3382 & 3 & 3 & & 1.04 & 1 & 49 & 43 \\
\hline & E04 & 13.2351 & 1.34 & 0.4663 & 0.52 & 0.39 & 0.2059 & 1.24 & 2467 & 13 & 2697 & 36 & 2873 & 36 & 14 & 0.0 & 0.79 & 75 & 96 & 51 \\
\hline & E17 & 8.5267 & 16.45 & 3044 & 14.62 & 0.89 & 0.2031 & 7.53 & 1713 & 250 & 2289 & 376 & 2852 & 21 & 40 & 0022 & 0.31 & 81 & 265 & 105 \\
\hline & E24 & .9777 & 1.14 & 0.5685 & 0.80 & 0.71 & 0.2038 & 0.80 & 2902 & 23 & 2875 & 33 & 2857 & 23 & -2 & 0.0002 & 0.47 & 58 & 126 & 94 \\
\hline & E06 & 2.8810 & 2.56 & 0.5035 & 2.27 & 0.88 & 0.1855 & 1.19 & 2629 & 60 & 2671 & 68 & 2703 & 32 & 3 & 0.0004 & 0.42 & 26 & 62 & 41 \\
\hline & E08 & 13.6823 & 4.43 & 0.5304 & 4.08 & 0.92 & 0.1871 & 1.72 & 2743 & 112 & 2728 & 121 & 2717 & 47 & -1 & 0.0012 & 0.51 & 8 & 16 & 11 \\
\hline & E11 & 13.4722 & 1.92 & 0.5249 & 1.61 & 0.84 & 0.1862 & 1.04 & 2720 & 44 & 2713 & 52 & 2709 & 28 & 0 & 0.0004 & 0.57 & 34 & 59 & 41 \\
\hline & E21 & 3. & 5.3 & 0.2057 & 2.9 & 0.55 & 65 & 4.43 & 1206 & 35 & 1608 & 86 & 2183 & 97 & 45 & & 0.26 & 122 & 470 & 128 \\
\hline & E28 & 4.5974 & 2.18 & 0.2405 & 1.66 & 0.76 & 0.1386 & 1.41 & 1390 & 23 & 1749 & 38 & 2210 & 31 & 37 & 0.0003 & 0.32 & 159 & 505 & 106 \\
\hline
\end{tabular}


from those of the first population and that characterize them as inherited zircons. One of the populations is represented by zircons E04, E17, and E24. These crystals are stubby or prismatic with rounded terminations. BSE imaging revealed ample homogeneous internal domains surrounded by faded

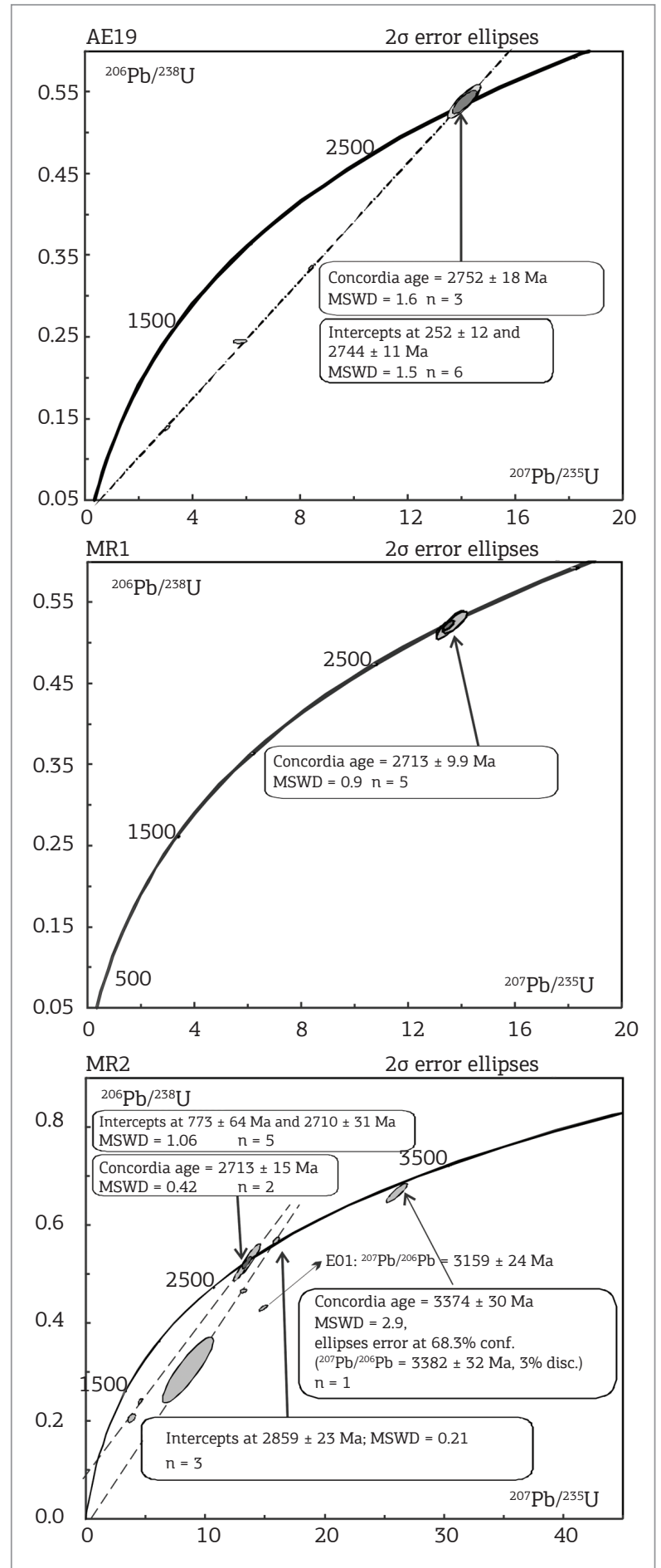

Figure 5. Wetherill Concordia diagrams for Carmópolis de Minas Layered Suite rocks. overgrowths or occasional fractures (zircon E17). Weakly contrasting BSE images suggest the presence of transgressive recrystallizations. All the crystals presented late fractures with fluid percolation and mineral inclusions. The analyses showed high and variable discordance (between 2 and 40\%; see Tab. 1), moderate to high ${ }^{232} \mathrm{Th} /{ }^{238} \mathrm{U}$ ratios $(\approx$ $0.31-0.79)$, and apparent ${ }^{207} \mathrm{~Pb} /{ }^{206} \mathrm{~Pb}$ ages ranging between $2873 \pm 36$ and $2852 \pm 21 \mathrm{Ma}$. This heterogeneity isotopic is apparently correlated with the presence of the fractures in the grains. The analytical points defined a Pb-loss cord with reasonably linear data array that intercepts the upper Concordia at $2859 \pm 23 \mathrm{Ma}(\mathrm{MSWD}=0.21)$ and lower Concordia at a meaningless geological age.

The third population is represented by zircons E01 and E27, with high ${ }^{232} \mathrm{Th} /{ }^{238} \mathrm{U}$ ratios. These zircons are ovoid to prismatic with rounded terminations, ample homogeneous domains, and blurred overgrowth. The zircon E01 yielded an extremely discordant analysis (24\% discordance), which resulted in an apparent ${ }^{207} \mathrm{~Pb} /{ }^{206} \mathrm{~Pb}$ age of $3159 \pm 24 \mathrm{Ma}$. Grain E27 yielded a sub-concordant result (3\% discordance) and apparent ${ }^{207} \mathrm{~Pb}^{206} / \mathrm{Pb}$ age of $\approx 3382 \pm 33 \mathrm{Ma}$, enabling the calculation of an isolated Concordia age of $3374 \pm 30 \mathrm{Ma}$ (MSWD = 2.9; Fig. 5).

\section{DISCUSSION AND CONCLUSIONS}

Although the BSE images do not allow for a clear view of the internal features of the zircon grains, the external morphology in association with ${ }^{232} \mathrm{Th} /{ }^{238} \mathrm{U}$ ratios can lead to some interpretations. The BSE imaging of zircon grains, as previously presented, revealed stubby (short prismatic) to prismatic habits (preferentially), with sub-rounded overgrowths and possible internal euhedral zoning. This morphology is consistent with zircons that underwent metamorphism in the upper-amphibolite to granulite facies conditions (see Vavra et al. 1999, Corfu et al. 2003, Hoskin \& Schaltegger 2003). Several studies have interpreted higher ${ }^{232} \mathrm{Th} /{ }^{238} \mathrm{U}$ ratios in high-grade metamorphic zircons from felsic (e.g. Schaltegger et al. 1999; Hoskin \& Black 2000) and mafic protolith (e.g. Vavra et al. 1999; Liati \& Gebauer 1999; Rubatto et al. 1999) as a magmatic signature. Although there is no consensus on the interpretations of this feature, the ${ }^{232} \mathrm{Th} /{ }^{238} \mathrm{U}$ ratios tend to be higher for granulite facies zircons than for eclogite and amphibolite facies zircons (Vavra et al. 1999). Work by Rubato (2002) showed that zircons from metamorphic eclogite have chemical compositions similar to igneous zircons; however, they have lower ${ }^{232} \mathrm{Th} /{ }^{238} \mathrm{U}$ ratios $(<0.1)$. The low ${ }^{232} \mathrm{Th} /{ }^{238} \mathrm{U}$ ratios may indicate a complete recrystallization of zircon and consequently reset of the isotopic systems (Hoskin \& Schaltegger 2003). In this sense, 
studies on eclogite and mafic-ultramafic granulite (e.g. Liati \& Gebauer 1999) have considered high ${ }^{232} \mathrm{Th} /{ }^{238} \mathrm{U}$ ratios from zircons with little or no preserved magmatic domains, as a pre-metamorphic heritage, and correlated ages are interpreted as the minimum age for crystallization of the protolith. This is the case of the U-Pb zircon dating from CMLS rocks.

The obtained ages between $\approx 3374$ and $2710 \mathrm{Ma}$ are recurrent in the Southern CSF (e.g. Teixeira et al. 1998; Noce et al. 2005; Hartman et al. 2006). In accordance with the studies of Teixeira (1996, 1998), Hartmann et al. (2006), and Lana et al. (2013), this age range records four magmatic events that occurred between the Paleo- and Neoarchean at the South São Francisco Craton.

Analyses of the amphibolite AE19 yielded a discordant upper intercept age of $2744 \pm 11 \mathrm{Ma}$ (MSWD $=1.5-$ Fig. 5), which we interpret as a reasonable approximation to the age of the tholeiitic magmatic phase in the Carmópolis de Minas Layered Suite. However, because of restrictions regarding the areas not clearly preserved in the magmatic zircons sampled, we interpret the apparent Concordia age of $2752 \pm 18 \mathrm{Ma}$ as being the most likely crystallization age of the amphibolite protolith and the minimum age of tholeiitic magmatism of the CMLS. This interpretation is also supported by the predominant low $\mathrm{Mg} \#$ (<57.87) of this suite, indicating that the protoliths of the studied tholeiitic rocks were not crystallized from primary magmas, but from evolved magmas that were previously fractionated into the crust (Goulart et al. 2013 in preparation). The presented results point that the CMLS tholeitic magmatic phase represents a period of emersion of oceanic arcs (Fig. 6A) during ETRV, which contributed to the formation of the Campo Belo Metamorphic Complex. According to Hartmann et al. (2006), the age of $\approx 2.75 \mathrm{Ga}$ represents the Rio das Velhas Orogeny apex $(\approx 2759-2751 \mathrm{Ma})$ in the southern São Francisco Craton.

The sample MR1 yielded a weighted mean ${ }^{206} \mathrm{~Pb} /{ }^{207} \mathrm{~Pb}$ age of $2718 \pm 19 \mathrm{Ma}$. This result overlaps within error with the upper intercept age of $2710 \pm 31 \mathrm{Ma}(\mathrm{MSWD}=1.06$ ) that was obtained in sample MR2 and constrains a likely age range for the development of the calc-alkaline magmatism recorded in the CMLS. Some field correlations that we presented in this work suggest the possibility of the fact that the calcium-alkaline magmatic phase might have occurred in several pulses. Therefore, we interpret the Concordia ages of $\approx 2713 \mathrm{Ma}$, which the samples MR1 and MR2 yielded, as the crystallization age of the metarhyolite protolith.

The ages of the samples MR1 and MR2 show that the CMLS calc-alkaline magmatic phase is slightly younger than the felsic magmatism of the Rio das Velhas Supergroup $(\approx 2746 \mathrm{Ma})$ in the Quadrilátero Ferrífero domain
(Machado et al. 1992; Noce et al. 2005; Hartmann et al. 2006). However, the magmatic protolith ages of the metamorphosed acidic rocks are contemporaneous to several granitoids, commonly described in metamorphic complexes present in the outskirts of QF (Romano 1989; Carneiro 1992; Noce 1995; Romano et al. 2013) that now are associated with the Neoarchean potassic magmatic event defined by Romano et al. (2013) and Lana et al. (2013). Other granitoids mark the development of continental margin, at the SW limit of the QF, in the region currently represented by the Bonfim Metamorphic Complex (e.g. Carneiro 1992; Machado \& Carneiro 1992; Campos \& Carneiro 2008; Lana et al. 2013). In contrast, the spatial and temporal correlations between the SACM and these rocks suggest that to the southwest, the convergence margin of the segment currently represented by Campo Belo Metamorphic Complex may have been characterized by the development of oceanic arcs parallel to the continental edge, defining one accretionary edge (Fig. 6C). Inside the continental block and in response to the evolution of a convergent margin, the development of an extensional environment supports the intrusion of the Ribeirão dos Motas Layered Sequence (Fig. 6C), whose whole-rock isochron age of $c a .2790 \mathrm{Ma}$ (Carneiro et al. 2004) overlaps within error with the 2752 $\pm 18 \mathrm{Ma}$ age obtained for the amphibolite AE19.

At the moment, the difference that we observe between the ages of the amphibolite AE19 and metarhyolite MR1 and MR2 rules out the possibility of magmatic hybridization as an explanation to the structures observed in the contact between the tholeiitic and calc-alkaline phases; on the other hand, it strengthens the thesis of assimilation and metasomatism of the preexisting amphibolite crust by acidic melts. However, the presence of reliquiar compositional banding with the accumulation of poikilitic hornblende/orthopyroxene or microgranular mafic aggregates indicates that physical-chemical instability occurred in the contact between magmas with distinct rheological characteristics (see Lindberg \& Eklund 1988). This observation still suggests that possibly other phases of calc-alkaline magmatism, not yet identified, could have coexisted with the tholeiitic magmatism along the CMLS evolution.

Tectonic models correlate the calc-alkaline magmatism genesis with the anatexis of the mafic sub-arc crust (e.g. Stern 2010), where the crustal emplacement of intermediate to felsic magmas records the beginning of the intermediate maturity stages of arc evolution, well defined by the formation of a felsic middle crust (Fig. 6B). The mafic lower crust was formed during infant and juvenile stages of the subduction and arc-related magmatism by the gradual replacement of the preexisting mafic-ultramafic oceanic crust. Presumably, the formation age of the initial mafic 
arc crust is constrained by the age of the CMLS tholeiitic magmatic phase and therefore must be equal to or older than $2752 \mathrm{Ma}$ (Fig. 6B). Development of juvenile arc-related magmatism would have involved the consumption and recycling of preexisting oceanic crusts and assimilation of crust-derived components.

Although the amphibolite AE19 has not presented direct evidence of crust-derived component assimilation, the sample MR2 records the presence of inherited zircons, with U-Pb ages ranging between $\approx 3374$ and $2859 \mathrm{Ma}$. These zircons represent a crustal inheritance that was passed from the lower arc crust to acidic melts during anatexis. Ages with this magnitude record two tectonic events that occurred between Paleo- and Mesoarchean, involving the development of continental nuclei and probable juvenile crust formation (see Machado \& Schrank 1989; Pimentel \& Ferreira Filho 2002; Hartmann et al. 2006; Lana et al. 2013). These events correspond to the Santa Barbara and Rio das Velhas I Events, according to that which was proposed by Lana et al. (2013), and reaffirm the formation of primitive (oceanic and continental) crustal nuclei at that period.

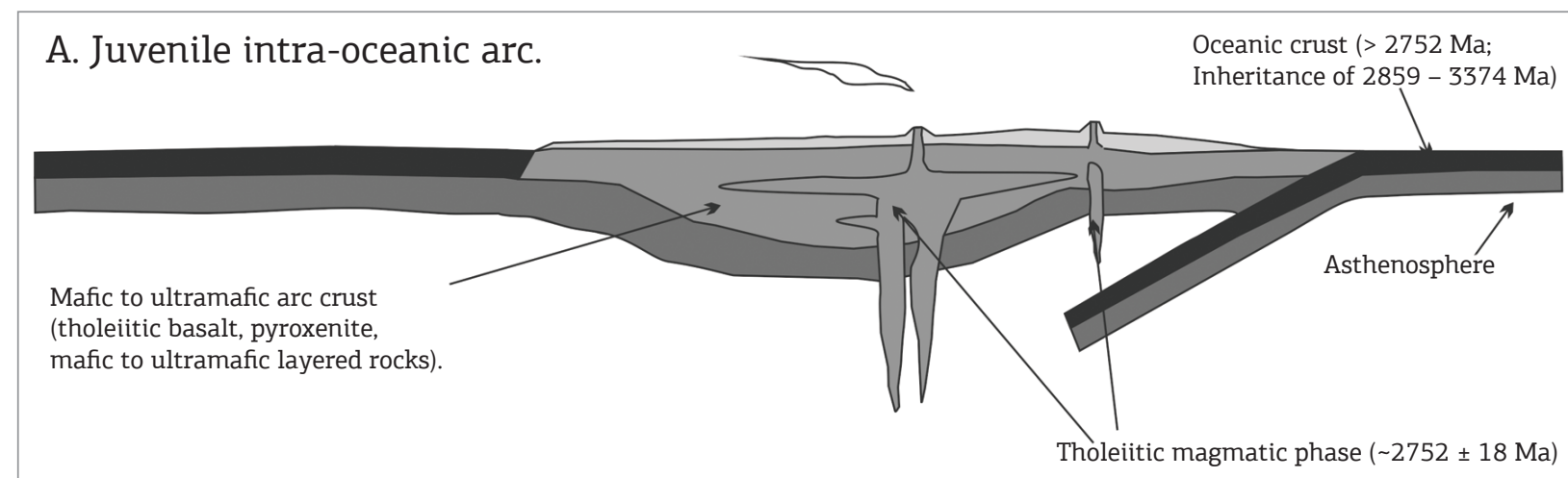

B. Juvenile to immature intra-oceanic arc.

Arc upper crust. Lavas, terrigenous and volcanogenic sediments Calc-alkaline magmatic phase $(\sim 2713 \pm 10 \mathrm{Ma})$. Development of felsic middle crust. (inconclusive or absent remains in the CMLS).

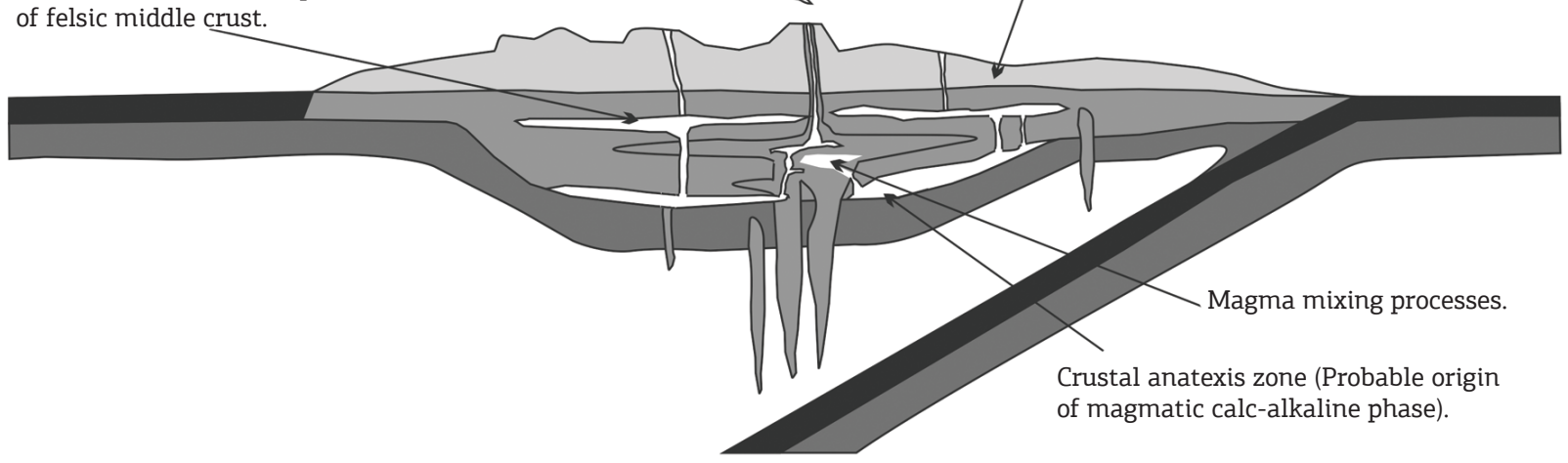

\section{Neoarchean regional geological setting.}

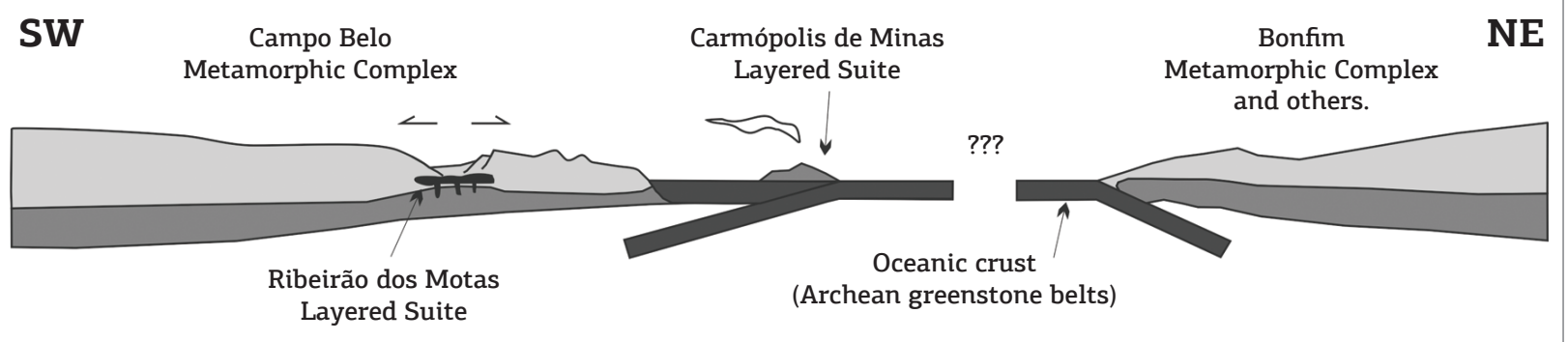

Figure 6. Schematic model for the evolution of the Carmópolis de Minas Layered Suite arc magmatism (based on Stern 2010). (A) Juvenile arc. Tholeiitic magmatism (amphibolite, mafic, and ultramafic cumulates). (B) Late to mature arc. Crustal thickening and beginning of calc-alkaline magmatism by sub-arc crust anatexis. (C) Tectonic model showing the genesis of the SACM. Observe correlation with Ribeirão dos Motas Layered Sequence. 
Unpublished work by Goulart \& Carneiro (2013, submitted), which supports the proposition of this model, was based on $\mathrm{Nd}-\mathrm{Sr}$ isotope data from a representative part of the lithological framework that composes the Carmópolis de Minas Layered Suite. The authors report a significant isotopic data set that includes several positive to slightly negative $\varepsilon_{\mathrm{Nd}(\mathrm{t})}$ parameters, variable $\varepsilon_{\mathrm{Sr}(\mathrm{t})}$ parameters, a pseudo-isochron age for CMLS of $2736 \pm 300$ Ma with $\varepsilon_{\mathrm{Nd}(\mathrm{i})}=+0.4$, and six $\mathrm{Sm}-\mathrm{Nd} \mathrm{T}_{\mathrm{DM}}$ model ages ranging from $\approx 3266$ to $2860 \mathrm{Ma}$. From these results we can highlight the following:

- The pseudo-isochron age is consistent with the ages that we have presented in this paper, whereas the slightly positive value of $\varepsilon_{\mathrm{Nd}(\mathrm{i})}$ reflects the affinity mantle of the primitive protolith of the CMLS.

- The Sm-Nd $\mathrm{T}_{\mathrm{DM}}$ model age range constrains, with a best approximation, the age of the magma sources and characterizes an isotopic inheritance from protolith that has been involved in the arc-magmatism or in sub-arc crust formation.

- Whole-rock analysis carried out in amphibolite, similar to sample AE19, yielded positive $\mathrm{e}_{\mathrm{Nd}(2713)}$ and $\mathrm{e}_{\mathrm{Sr}(2713)}$ parameter values, with an $\mathrm{Sm}-\mathrm{Nd}_{\mathrm{DM}}$ model age of $\approx 2985 \mathrm{Ma}$, indicating that the tholeiitic primordial magmas were originated in depleted mantle sources and later, during emplacement in the crust, they assimilated older crustal components.

- The single metarhyolite sample (MR1) yielded a Sm-Nd TDM model age of $\approx 2860 \mathrm{Ma}$, older than the suite, although newer than Sm-Nd TDM model ages of the other samples. Thus, the genesis of the protolith of this rock can be linked to sub-arc crust anatexis, a fact corroborated by the slightly negative $\varepsilon_{\mathrm{Nd}}(2713)$ values $(-0.25)$ and positive $\varepsilon_{\mathrm{Sr}}(2713)$ values $(+12)$, suggesting a protolith correlated to juvenile crustal reservoir, with short crustal residence time. The Sm-Nd TDM model age of $2860 \mathrm{Ma}$ replicates within error the upper intercept age that was obtained in the $\approx 2859$ Ma inherited zircons (E04, E17, and E24) of sample MR2, confirming the probable age of one of the crusts involved in the sub-arc crust formation.

Thus, the development of the Carmópolis de Minas Layered Suite occurred in a restricted range time (2752 $2710 \mathrm{Ma}$ ), during the last $40 \mathrm{Ma}$ of the Rio das Velhas Orogeny. In this period, the crustal segments that currently compose the Campo Belo Metamorphic Complex consisted of isolated young crustal nuclei that were agglutinated between Rio das Velhas Orogeny and potassic magmatism after this. At the end of the Neoarchean events, the isolated continental nuclei, including the younger protocontinental segments and the last magmatic arcs (e.g. CMLS), were amalgamated, starting the architecture and stabilization of the Archean platform that preceded the Proterozoic events and presently represents the sialic substrate of this portion of the Sáo Francisco Craton.

\section{ACKNOWLEDGMENTS}

We wish to thank FAPEMIG for the financial support for the projects (MAC; CRA - RDP-00067-10), Capes for the doctoral scholarship (LEAG), and CNPq for the productivity scholarship (MAC). We would also like to thank Editor Cordani, U. and all anonymous reviewers for constructive comments.

\section{REFERENCES}

Campos J.C.S \& Carneiro M.A. 2008. Neoarchean and Paleoproterozoic granitoids marginal to the Jeceaba-BomSucesso lineament (SE border of the southern São Francisco craton): Genesis and tectonic evolution. Journal of South American Earth Sciences, 26:463-484.

Carneiro M.A. 1992. O Complexo Metamórfico Bonfim Setentrional - Quadrilátero Ferrífero, Minas Gerais: litoestratigrafia e evolução geológica de um segmento de continental do arqueano. Tese de Doutoramento, Instituto de Geociências, Universidade de São Paulo, São Paulo, 233 p.

Carneiro M.A., Jord-Evangelista H. \& Teixeira W. 1997. Eventos magmáticos arqueanos de natureza cálcio-alcalina e thoelítica no Quadrilátero Ferrífero e suas implicacões tectônicas. Revista Brasileira de Geociências, 27:121-128.

Carneiro M.A., Teixeira W., Carvalho Júnior I.M., Oliveira A.H. \& Fernandes R.A. 1997. Archean Sm/Nd isochron age from the Ribeirão dos Motas layered rocks sequence, Southern São Francisco
Craton, Brazil. In: South-American Symposium on Isotope Geology, Campos do Jordão. Extended Abstracts, p. 63-64.

Carneiro M.A., Teixeira W., Carvalho Junior I.M. \& Fernandes R.A. 1998. Ensialic Tectonic Setting of the Archaean Rio das Velhas Greenstone Belt: $\mathrm{Nd}$ and $\mathrm{Pb}$ Isotopic Evidence from the Bonfim Metamorphic Complex, Quadrilátero Ferrífero, Brazil. Revista Brasileira de Geociências, 28(2):189-200

Carneiro M.A., Teixeira W., Carvalho Jr. I.M., Pimentel M.M. \& Oliveira A.H. 2004. Comportamento dos Sistemas Sm-Nd e RbSr da Seqüência Acamadada Máfico-Ultramáfica Ribeirão dos Motas (Arqueano), Cráton São Francisco Meridional: Evidências de Enriquecimento Mantélico e Fracionamento Isotópico. Revista do Instituto de Geociências, Geologia USP Série Científica, São Paulo, 4(2):13-26.

Carneiro M.A., Endo I., Nalini Jr. H.A, Sales J.C.C., Goulart L.E.A., Silva E.F., Pereira A.A., Tavares T.D., Jiamelaro F, Carneiro J.M., Mariano 
L.C. Prado G.E.A., Urbano E.P.C., Santos C. \& Miguel F.P. 2007. Folha Oliveira escala: 1:100.000. Texto explicativo e mapa impresso, Belo Horizonte, Convênio CPRM/UFOP, 127 p.

Carvalho Jr. I.M. 2001. Petrologia e Geologia de Rochas Ultramáficas Arqueanas do Cráton São Francisco Meridional: A Seqüência Acamada Ribeirão dos Motas. Dissertação de Mestrado. Departamento de Geologia, Escola de Minas, Universidade Federal de Ouro Preto, 96 p.

Chemale Jr. F., Kawashita K., Dussin I.A., Avila J.N., Justino D. \& Bertotti A.L. 2009. U-Pb zircon dating with MC-ICP-MS using mixed detector configuration. Relatório Interno, Porto Alegre, UFRGS. 36 p.

Chemale Jr. F., Kawashita K., Dussin I.A. \& Justino D. 2008. Age Comparison Between U-Pb Zircon Dating with LA-MC-ICP-MS Using Mixed Detector Configuration and SHRIMP. In: South American Symposium on Isotope Geology 6, San Carlos de BarilocheArgentina, Book of Extended Abstracts, CD-Rom.

Connelly J.N. 2000. Degree of preservation of igneous zonation in zircon as a signpost for concordance in $\mathrm{U}-\mathrm{Pb}$ geochronology. Chemical Geology, 172:25-39.

Corfu F., Hanchar J.M., Hoskin P.W.O., Kinny P. 2003. Atlas of zircon textures. In: Hanchar J. M. \& Hoskin W. O. P. (eds). Zircon. Reviews in Mineralogy and Geochemistry 53:468-500

Gill J. 1981. Orogenic Andesites and Plate Tectonics. Springer, 390 p.

Goulart L.E.A. \& Carneiro M.A. 2013 (in press). Evolution of arc magmatism in the Carmópolis de Minas Layered Suite, Minas Gerais, Brazil: Sm-Nd and Rb-Sr isotope geochemistry. Revista Escola de Minas (no date to be published).

Goulart L.E.A., Carneiro M.A. \& Suita, M.T.F. 2013 (unpublished). Caracterização de um episódio de Arco-Magmatismo Neoarqueano no Cráton São Francisco Meridional: Intrusão acamadada Carmópolis de Minas, MG, Brasil.

Hartmann L.A., Endo I., Suita M.D.F., Santos J.O.S., Frantz J.C., Carneiro M.A., McNaughton N.J. \& Barley M.E. 2006. Provenance and age delimitation of Quadrilátero Ferrífero sandstones based on zircon U-Pb isotopes. Journal of South American Earth Sciences, 20:273-285.

Hoskin P.W.O. \& Black L.P. 2000. Metamorphic zircon formation by solid-state recrystallization of protolith igneous zircon. Journal of Metamorphic Geology, 18:423-439.

Hoskin P.W.O. \& Schaltegger U. 2003. The Composition of Zircon and Igneous and Metamorphic Petrogenesis. In: Hanchar J.M. \& Hoskin P.W.O. (eds) Zircon. Reviews in Mineralogy and Geochemistry, 53:27-62.

Hawkins J.W. \& Ishizuca O. 2009. Petrologic evolution of Palau, a nascent island arc. Island Arc, 18:599-641.

Jackson S.E., Pearson N.J., Griflin W.L. \& Belousova E.A. 2004. The application of laser ablation-inductively coupled plasma-mass spectrometry to in situ U-Pb zircon geochronology. Chemical Geology, 211:47-69.

Kawashita K. \& Chemale Jr. F. 2006. ICP/MS(MC) as an instrument in isotope geology. In: Conferência no V SSAGI - V Simposio Sudamericano de Geologia Isotopica, Punta Del Este, v.1.

Lana C., Alkmin F., Richard Armstrong R., Scholz R., Romano R. \& Nalini Jr. H.A. 2013. The ancestry and magmatic evolution of Archaean TTG rocks of the Quadrilátero Ferrifero province, southeast Brazil. Precambrian Research, 231:157-173.

Leat P.T., Smellie J.L., Millar I.L. \& Larter R.D. 2003, Magmatism in the south Sandwich arc. In: Larter, L.D. \& Leat, P.T. (eds.) Intraoceanic subduction systems: Tectonic and magmatic processes. Geological Society (London) Special Publication, 219:239-254.

Leite C.A.S., Perrotta M.M., Silva L.C., Silva M.A., Heineck C.A., Salvador E.D., Vieira V.S., Lopes R.C., Silva M.G.M., Drumond J.B.V.,
Malouf R.F., Lacerda Filho J.V., Valente C.R., Gomes S.D., Sachs L.L.B., Oliveira I.W.B., Ramgrab G.E., Netto C., Junqueira P.A. \& Paes V.J.C. 2004. Folha SF.23 - Rio de Janeiro. In: Schobbenhaus. C., Gonçalves J.H., Santos J.O.S., Abram M.B., Leão Neto R., Matos G.M.M., Vidotti R.M., Ramos M.A.B. \& Jesus J.D.A. (eds). Carta Geológica do Brasil ao Milionésimo, Sistema de Informações Geográficas. Programa Geologia do Brasil. CPRM. Brasília. CD-ROM.

Liati A. \& Gebauer D. 1999. Constraining the prograde and retrograde P-T- t path of Eocene HP rocks by SHRIMP dating different zircon domains: inferred rates of heating, burial, cooling and exhumation for central Rhodope, northern Greece. Contributions to Mineralogy and Petrology, 135:340-354.

Lindberg B. \& Eklund O. 1988. Interactions between basaltic and granitic magmas in a Svecofennian postorogenic granitoid intrusion, Aland, southwest Finland, Lithos, 22:13-23.

Ludwig K.R. 2000. Isoplot 3.0: A Geochronological Toolkit for Microsoft Excel, vol. 4. Berkeley Geochronology Center Special Publication, 71 p. (CD).

Machado N. \& Carneiro M.A. 1992. U-Pb evidence of late Archean tectono-thermal activity in the southern São Francisco shield, Brazil. Canadian Journal of Earth Science, 29:2341-2346.

Machado A. \& Schrank A. 1989. Geocronologia U-Pb do Maciço de Piumhí: resultados preliminares. In: Simpósio de Geologia de Minas Gerais, V, 1989. Belo Horizonte. Anais. Belo Horizonte: SBG, p. 45-49.

Machado N., Schrank A., Noce C.M. \& Gauthier G. 1996. Ages of detrital zircon from archean paleoproterozoic sequences: implications for greenstone belt setting and evolution of a transamazonian foreland basin in Quadrilátero Ferrífero, southeast Brazil. Earth Planetary Science Letters, 141:259-276.

Machado N., Noce C.M., Ladeira E.A., Oliveira O.A.B. 1992. $\mathrm{U}-\mathrm{Pb}$ geochronology of Archean magmatism and Proterozoic metamorphism in the Quadrilátero Ferrífero, Southern São Francisco Craton, Brazil. Geological Society of American Bulletin, 104:1221-1227.

Morgan G.B. \& London D. 1987. Alteration of amphibolitic wallrocks around the Tanco rare-element pegmatite, Bernic Lake, Manitoba, American Mineralogist, 72:1097-1121

Noce C.M. 1995. Geocronologia dos eventos magmaticos, sedimentares e metamorficos na regiao do Quadrilátero Ferrífero, Minas Gerais. Tese de Doutoramento, Instituto de Geociências, Universidade de São Paulo, São Paulo, 128 p.

Noce C.M., Machado N. \& Teixeira W. 1998. U/Pb Geochronology of gnaisses and granitoids in the Quadrilátero Ferrífero (Southern São Francisco Craton): age constraints for archean and paleoproterozoic magmatism and metamorphism. Revista Brasileira de Geociências, 1(28):95-102.

Noce C.M., Zuccheti M., Baltazar O.F., Armstrong R.C., Dantas E., Renger F.E.A. \& Lobato L.M. 2005. Age of felsic volcanism and the role of ancient continental crust in the evolution of the Neoarchean Rio das Velhas Greenstone belt (Quadrilátero Ferrífero, Brazil): U-Pb zircon dating of volcaniclastic graywackes. Precambrian Research, 141: $67-82$

Pimentel M. \& Ferreira Filho C.F. 2002. Idade Sm-Nd de komatiitos do greenstone belt do Morro do Ferro, Fortaleza de Minas (MG). Revista Brasileira de Geociências, 32(1):147-148.

Pinese J.P.P. 1997. Geoquímica, geologia isotópica e aspectos petrológicos dos diques máficos pré-cambrianos da região de Lavras (MG), Porção Sul do Cráton São Francisco. Tese de Doutorado, Instituto de Geociências, Universidade de São Paulo, São Paulo, 178 p.

Romano A.W. 1989. Evolution tectonique de la region NW du Quadrilatere Ferrifere - Minas Gerais, Brasil. Nancy. These. Docteur, Universite de Nancy, Franca, 259 p. 
Romano R., Lana C., Alkmim F.F., Stevens G. \& Armstrong R. 2013. Stabilization of the southern portion of the São Francisco craton, SE Brazil, through a long-lived period of potassic magmatism. Precambrian Research, 224:143-159.

Rubatto D. 2002. Zircon trace element geochemistry: partitioning with garnet and the link between U-Pb ages and metamorphism. Chemical Geology, 184:123-138.

Rubatto D., Gebauer D. \& Compagnoni R. 1999. Dating of eclogite-facies zircons: the age of Alpine metamorphism in the Sesia-Lanzo Zone (Western Alps). Earth and Planetary Science Letters, 167:141-158.

Schaltegger U., Fanning C.M., Gunther D., Maurin J.C., Schulmann K. \& Gebauer D. 1999. Growth, annealing and recrystallization of zircon and preservation of monazite in high-grade metamorphism: conventional and in situ $\mathrm{U}-\mathrm{Pb}$ isotope, cathodoluminescence and microchemical evidence. Contribuions to Mineralogy and Petrology, 134:186-201.

Seaman S.J., Scherer E.E. \& Standish J.J. 1995. Multistage magma mingling and the origin of flow banding in the Aliso lava dome Tumacacori Mountains, southern Arizona. Journal of Geophysical Research, 100:8381-8398.

Silva L.C., Noce C.M. \& Lobato L.M. 2000. Dacitic volcanism in the course of the Rio das Velhas (2800-2960 Ma) Orogeny: a Brazilian Archean analogue (TTD) to the modern adakites. Revista Brasileira de Geociências, 30:384-387.

Stacey J.S. \& Kramers J.D. 1975. Approximation of terrestrial lead isotope evolution by a two-stage model. Earth and Planetary Science Letters, 26:207-221.

Stern R.J. 2010. The anatomy and ontogeny of modern intra-oceanic arc systems. In: Kusky T.M., Zhai M.G. \& Xiao W. (eds), The Evolving Continents: Understanding Processes of Continental Growth, Geological Society, London, Special Publications, 338:7-34.
Storey M., Wolff J. A., Norry M.J. \& Marriner G.F. 1989. Origin of hybrid lavas from Água de Pau volcano, São Miguel, Azores. In: Sunders A.D. \& Norry M.J. (Eds). Magmatism in Ocean Basins. Geological Society of London, Special Publications, Classics, p. 161-180

Tamura Y. 2003. Some geochemical constraints on hot fingers in the mantle wedge: evidence from NE Japan. In: Larter R.D. \& Leat P.T. (eds), Intra-Oceanic Subduction Systems: Tectonic and Magmatic Processes. Geogical Society, London, Special Publications, 219:221-237.

Teixeira W. 1985. A evolução geotectônica da porção meridional do Craton do São Francisco, com base em interpretações geocronológicas. Tese de Doutoramento, Instituto Geociências, Universidade de São Paulo. São Paulo, 207 p.

Teixeira W., Carneiro M.A., Noce C.A., Machado N., Sato K. \& Taylor P.N. \& 1996. Pb, Sr and Nd isotope constraints on the Archean evolution of gneissic granitoid complexes in the southern São Francisco Craton, Brazil. Precambrian Research, 78:151-164.

Teixeira W., Cordani U.G., Nutman A.P. \& Sato K. 1998. Polyphase archean evolution in the Campo Belo Metamorphic Complex, Southern São Francisco Craton, Brazil: shrimp and U-Pb zircon evidence. Journal of South American Earth Science, Oxford, 3(11): 279-289.

Teixeira W., Sabate P., Barbosa J.S.F., Noce C.M. \& Carneiro M.A., 2000. Archean and Paleoproterozoic Tectonic evolution of the São Francisco Craton, Brazil. In: Cordani, U.G., Milani, E.J., Thomas Filho, A., Campos, D.A. (Eds.), Tectonic Evolution of the South America, v.31. International Geologic Congress, Rio de Janeiro, Brazil, p. 101-137.

Vavra G., Schmid R. \& Gebauer D. 1999. Internal morphology, habit and U-Th- $\mathrm{Pb}$ microanalysis of amphibolites to granulite facies zircons: geochronology of the Ivrea zone (Southern Alps). Contribution to Mineralogy and Petrology, 134:380-404. 